\title{
Hospital networks and patient transport capacity during the COVID-19 pandemic when intensive care resources become scarce
}

\author{
Alexander Supady ${ }^{1,2,3^{*}}$ (D) Dawid Staudacher ${ }^{1,2}$, Christoph Bode ${ }^{1,2}$, Guido Michels ${ }^{4}$ and Tobias Wengenmayer ${ }^{1,2}$
}

With great interest we read the article by Heinsar et al. discussing implications for extracorporeal membrane oxygenation (ECMO) during the coronavirus disease 2019 (COVID-19) pandemic when the number of patients reaches a level that demand may overwhelm available resources [1].

While various medical resources could become scarce during a pandemic, ECMO is exposed for numerous reasons. Firstly, it is a potentially lifesaving treatment for patients that would die without; secondly, ECMO treatment is highly resource intensive and therefore may have an impact on the availability of resources for other patients [2].

Crisis standards of care may include strategies for rationing of scarce resources [3]. However, before withholding potentially lifesaving therapy including ECMO from patients in need, all reasonable efforts must be made to maintain ordinary standard of care [4].

During the COVID-19 pandemic, disease hotspots emerged, where healthcare facilities were overwhelmed and provision of standard of care was challenged or even impossible. Examples include Wuhan (China), Bergamo (Italy), New York (United States) and Heinsberg (Germany). However, at the same time, even within these affected countries, healthcare capacities were still available.

\footnotetext{
*Correspondence: alexander.supady@universitaets-herzzentrum.de ${ }^{1}$ Department of Medicine III (Interdisciplinary Medical Intensive Care), Medical Center - University of Freiburg, Faculty of Medicine, University of Freiburg, Freiburg, Germany

Full list of author information is available at the end of the article
}

In case of imminent local overstrain, networks could be established to transfer patients to regions with lower case numbers, whether nearby or further away (Fig. 1) [5]. Thoughtful and responsible planning should include making information about free hospital and ICU beds and other potentially scarce healthcare resources, like ventilators or ECMO, at the local, regional and national level easily available to physicians. Furthermore, governments, administrations, and healthcare managers should provide transport capacity to transfer patients from congested regions to less affected regions where there are still hospital resources available. In France, when some regions were particularly affected by the pandemic, passenger trains were temporarily converted for the transfer of intensive care patients.

Registries monitoring the availability of ICU beds and definition of regional clusters for patient allocation help to ease pressure from overburdened hospitals, too. This model could be established elsewhere.

Triage committees or advanced prediction models may support decision makers in preparing for situations of scarcity; however, as soon as important resources are no longer available in sufficient quantities, structures and procedures must be in place that healthcare workers can access without any particular hurdles in order to refer or transfer patients to the places where the necessary resources are (still) available. In such situations triage committees or prediction models most likely cannot keep up with the pace and flexibility required.

\section{Acknowledgements}

None.

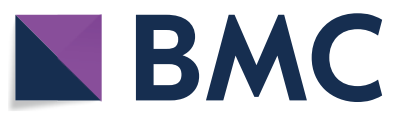

(c) The Author(s) 2021. Open Access This article is licensed under a Creative Commons Attribution 4.0 International License, which permits use, sharing, adaptation, distribution and reproduction in any medium or format, as long as you give appropriate credit to the original author(s) and the source, provide a link to the Creative Commons licence, and indicate if changes were made. The images or other third party material in this article are included in the article's Creative Commons licence, unless indicated otherwise in a credit line to the material. If material is not included in the article's Creative Commons licence and your intended use is not permitted by statutory regulation or exceeds the permitted use, you will need to obtain permission directly from the copyright holder. To view a copy of this licence, visit http://creativecommons.org/licenses/by/4.0/. The Creative Commons Public Domain Dedication waiver (http://creativeco mmons.org/publicdomain/zero/1.0/) applies to the data made available in this article, unless otherwise stated in a credit line to the data. 


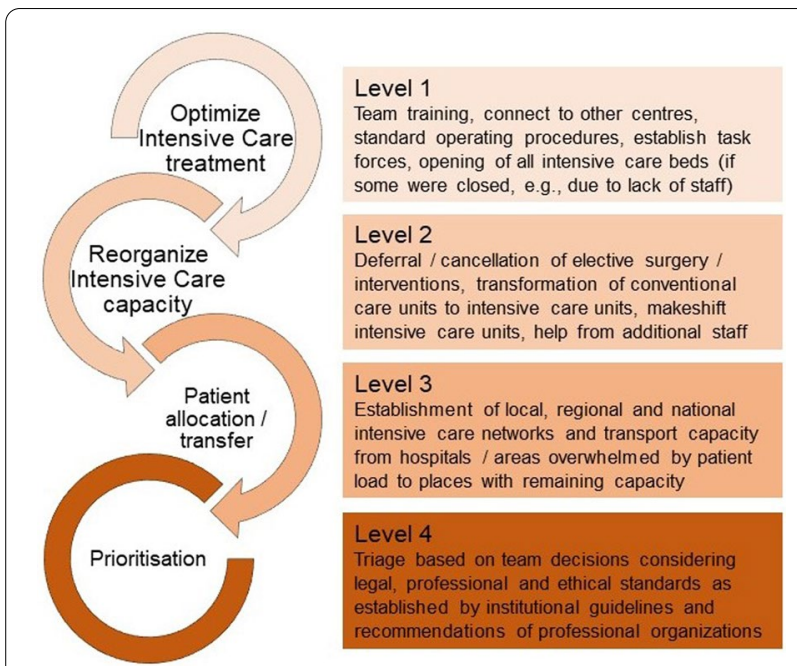

Fig. 1 Levels for gradually moving from standard of care to crisis standard of care when intensive care unit resources become scarce during the COVID-19 pandemic

\section{Authors' contributions}

AS designed the paper and prepared the first draft based on preceding discussions with all co-authors. All authors reviewed the draft and approved the final version of the manuscript.

\section{Availability of data and material \\ Not applicable.}

Ethics approval and consent to participate

Not applicable

\section{Consent for publication}

Not applicable.

\section{Competing interests}

The authors declare that they have no competing interests.

\section{Author details}

${ }^{1}$ Department of Medicine III (Interdisciplinary Medical Intensive Care), Medical Center - University of Freiburg, Faculty of Medicine, University of Freiburg, Freiburg, Germany. ${ }^{2}$ Department of Cardiology and Angiology I, Heart

Center, University of Freiburg, Hugstetter Strasse 55, 79106 Freiburg, Germany. ${ }^{3}$ Heidelberg Institute of Global Health, University of Heidelberg, Heidelberg, Germany. ${ }^{4}$ Department of Acute and Emergency Care, St. Antonius Hospital Eschweiler, Eschweiler, Germany.

Received: 26 November 2020 Accepted: 5 January 2021

Published online: 12 January 2021

\section{References}

1. Heinsar S, Peek GJ, Fraser JF. ECMO during the COVID-19 pandemic: when is it justified? Crit Care. 2020;24(1):650

2. Abrams D, Lorusso R, Vincent JL, Brodie D. ECMO during the COVID-19 pandemic: when is it unjustified? Crit Care. 2020;24(1):507.

3. Emanuel EJ, Persad G, Upshur R, Thome B, Parker M, Glickman A, Zhang C, Boyle C, Smith M, Phillips JP. Fair allocation of scarce medical resources in the time of Covid-19. N Engl J Med. 2020;382(21):2049-55.

4. Vincent JL, Creteur J. Ethical aspects of the COVID-19 crisis: how to deal with an overwhelming shortage of acute beds. Eur Heart J Acute Cardiovasc Care. 2020;9(3):248-52.

5. Ramanathan K, Antognini D, Combes A, Paden M, Zakhary B, Ogino M, MacLaren G, Brodie D, Shekar K. Planning and provision of ECMO services for severe ARDS during the COVID-19 pandemic and other outbreaks of emerging infectious diseases. Lancet Respir Med. 2020;8(5):518-26.

\section{Publisher's Note}

Springer Nature remains neutral with regard to jurisdictional claims in published maps and institutional affiliations.
Ready to submit your research? Choose BMC and benefit from:

- fast, convenient online submission

- thorough peer review by experienced researchers in your field

- rapid publication on acceptance

- support for research data, including large and complex data types

- gold Open Access which fosters wider collaboration and increased citations

- maximum visibility for your research: over $100 \mathrm{M}$ website views per year

At BMC, research is always in progress.

Learn more biomedcentral.com/submissions 